\title{
Reflects the Traditions in Contemporary Prose
}

Gabidullina F.I.

Sattarova G.G.

Yelabuga Institute of Kazan Federal University; farida-vip@mail.ru, gulnaz-sattarova@mail.ru

\author{
Doi:10.5901/mjss.2015.v6n5s2p201
}

\section{Abstract}

At the turn of XX - XXI centuries Tatar literature has experienced a number of changes. On the one hand, this is due to transfer to another stage of development, as the desire to cover the literature and culture of the new. In the second half of the twentieth century world literature and culture of the search begins. The paper deals with the reflection of the nation's history and traditions in contemporary prose. In recent years, many have come to the literature writers. They create works that takes place and national history, and love, and loneliness. This paper discusses the creation N.Gimatdinovoy who came into the literature with peculiar mc only to her special literary language. Article is devoted to the definition of a place of tradition and history in contemporary prose, and it was considered prose N.Gimatdinovoy. Reflection in prose tradition and its influence on modern literature - the essence of the article.

Keywords: tradition, history, the unity of man and nature, love of life, the price of freedom.

\section{Introduction}

Tradition - this term is used in the literature in relation to the continuity of communication, combining a series of successive literary phenomena, and in relation to the results of such a connection, to the stock of literary skills. Within the meaning of the tradition of his contact with the imitation, influence and borrowing, differing from them the fact that the traditional material, being recognized in the literary world, it is part of the art appliances, sanctioned by custom, have become common heritage - at the time, as an imitation, influence borrowing and deal with the material lying outside this environment, it is not yet internalized (Brodsky, 1925).

Tradition is often intertwined with the direct influence, imitation and borrowing. Tradition and innovation (Latin tradition - Transfer) - a transfer of artistic experience from one generation to the other artists continue the tradition - so creatively assimilate the experience of predecessors and move on (Hatipov F., 2000).

Material literary tradition can serve all the elements: subject matter, composition, style ... but most of the elements of these traditions are not transmitted separately, and in a combination with each other, in accordance with the ongoing relationship that exists between them in the art of speech in general.

The scope of the literary tradition can be the work of one nation and international creativity.

In any literary process - a combination of two principles: tradition and personal creativity. Where a person deepens tradition, we can talk about literary evolution.

Personal creativity can establish new traditions. And this can be done by reviving old traditions. By 1980 years of Tatar literature has already formed tradition. In prose comes to the fore the desire to fully disclose the relationship of man and society (Zakhidullina D., Zakirdganov A., Gilyazov T., 2004)

Ethnic and religious traditions, in turn, represent the traditions of one ethnic group. In the modern Tatar literature has many examples of ethnic heritage conservation, preservation of the people (Musin F., 1999).

\section{Research Methods}

All the tools and techniques used in the solution of interest nasproblem - from problem to the interpretation of the results - have been solved with the aid of various methods. The research method dictates specific techniques, tools issledovaniya.V as a method performed various operations and methods of data collection, systematization and classification of empirical facts and materials, which are largely determined by the methodological approach used by the researcher. As applied data collection and processing for some literary works, compilation and systematization, comparison, analysis and synthesis, deduction and induction of the collected material. 


\section{Literature Review}

I would like to refer to the work of typing Gimatdinovoy. One of the main themes in the work of the writer is the fate of the Tatar women. In many of his works N. Gimatdinova describes a failed happiness unfortunate life of women. Each of her heroines is unhappy in its own way. The author writes about love their heroes. But many of her heroines are mistaken in love, in some favorite men are weak, others do betray her love. Heroes of stories are by no means or negative or positive characters. They are many and good and bad. But in each outweighs or good or evil.

Protagonists N.Gimatdinovoy derive their strength in nature. They with nature - one link. The writer wants to bring people back to the bosom of nature, believing that the more a person by nature, the less he has human qualities such as kindness, love of neighbor, tenderness, understanding, conscience, honor, respect. The unity of man and nature is a tradition that has come in modern literature has long been. The writer wants to thus preserve the tradition of the unity of all life (http://www.cbs-kazan.ru/izdania-tatlitra12.htm.

She also wants to wake up in the readers love for history of Tatar people, to its rites, traditions and beliefs. In recent years, creativity N. Gimatdinova uses rich mythological characters, reveals centuries-old Dukhovoye wealth of the people. "Bewitched", "Wolfblood", "Kukushkin saliva" - such stories (Gyymatdinova N., 2006). These and other works of the 90s N. Gimatdinovoy raise the issue of human relationships, nature and unknown forces.

Her works make clear that a person without their history, without nature can not continue to evolve and grow. The most important enemy of the people of this generation, as the works of N. Gimatdinovoy is alcohol. If a person has no faith in the future and it lends itself to all the harmful action, then the future life will be doomed. This we see clearly in the story "Ak kargyshy the turn" (Gyymatdinova N., 2003).

\section{Conclusions}

Life stories, and at the same time, the lack of everyday routine do the work N. Gimatdinovoy popular. It aims to show readers the power of spirituality and morality. Appeal to tradition, the confrontation between good and evil are an integral part of the features of creativity of the writer.

I would like to see the story N.Gimatdinovoy "Sində Minh hakym bar " You owe me '(Gyymatdinova N., 2011). In this story the writer does not change its traditions: the happiness of man in harmony with nature. But here you can find a reflection of the nation's history. Describing the characters and the lives of the characters, it shows history. It has long been a Tatar village was proud people. It stands on the protection of all the sacred: religion is preserved in the villages, folk heritage there too. Tatar village reminiscent of grandmothers in white headscarves, the same pure, disinterested. But over time, and this purity leaves. Keeping up with the times, the village come alcohol, envy. People become slaves to their greed, do not see anything except his wealth. All are chasing money instead to appreciate what they have. Feature of creativity N.Gimatdinovoy be called parallel description of all the events. Present and past - they go together. That's a story our protagonist begins to remember Hafiz all my past ... And it all starts with the fact that the village will bring to bury Miңlekamal, the whole village knew her as Davyl. Davyl image is a reflection of history. She moved to the village with his granddaughter, no one knew anything about her life, but on May 9 she went to a rally in the orders and medals. During the war, even the women, not sparing himself, fought against the enemy. The war did not spare anyone and so against fascism rises, the Tatar people was no exception. Everyone wanted a quiet, peaceful life - it brings people together. People who have seen war firsthand, cherish a peaceful life, appreciate every moment. Davyl is such a person.

In the story the main character is a Hafiz. He spent his childhood near Davyl. She instilled in him a love of horses and justice. But no matter how fair and proper not Hafiz, his wife sells alcohol to the public. And according to the laws of Islam is - haram. That's because of all the traditions of alcohol in the villages began to disappear. People to work and earn money to buy himself a drink. All of this leads to the destruction of all that is holy (Zakhidullina D., 2005). The author shows it all so natural and vital. It transmits all through dreams, thoughts, characters and natural phenomena.

Finally, I would like to say that N. Gimatdinova proved to be a master of drawing up the storyline. Fantasy author intersects with the national history and thereby forms a coherent whole. Tired of loneliness, hypocrisy people looking for peace in nature is (Gyyniyatullina A., 2000). Spoiled society contrasted pure nature. Pure, sinless life is possible only in the bosom of nature. Nature retains all: the past and the present, silently watching the changes. based on the work of $\mathrm{N}$. Gimatdinova, I can say that the contemporary women's prose vividly reflect the traditions of the Tatar people. Also stays involved in the lives of ordinary people, because they, the inhabitants of villages and villages are the true keepers of all values. the author shows how, from year to year, depending on education, morality, society ceases to appreciate the traditions of our ancestors. in order to return, should, in the first government, to serve his people and to live by the laws of religion, of morality. 


\section{References}

Brodsky N. Ed. (1925). Literary Encyclopedia Dictionary of Literary. Terms:In 2 Vols. M .;L. Publishing House of LD Frenkel.

Gyyniyatullina A. (2000). The novelty in the literature Magrifat, Journal.

Gyymatdinova N. (2003). Lonely: the shed and stories. Kazan: Tat.kniga izdat.

Gyymatdinova N. (2006). Drop of love: the shed and stories. Kazan: Tat.kniga izdat.

Gyymatdinova N. (2011). You owe me. Kazan: Tat.kniga izdat.

Hatipov F. (2000). The literary theory: A handbook for students of the high schools, the pedagogical schools and the colleges. Kazan: Magariph.

http://www.cbs-kazan.ru/izdania-tatlitra12.htm

Musin. F. (1999).Tatar novel. The heritage. Kazan: Magariph... .

Zakhidullina. D (2005). The analyze of the literary composition. Kazan: Magariph.

Zakhidullina D., Zakirdganov A.,Gilyazov T. (2004) Tatar literature: The theory. The history. Kazan: Magariph. 